\title{
Evaluation of competitiveness of top-grades of ultrapasterized milk in the conditions of Covid-19
}

\section{ОЦЕНКА КОНКУРЕНТОСПОСОБНОСТИ ТОРГОВЫХ МАРОК УЛЬТРАПАСТЕРИЗОВАННОГО МОЛОКА В УСЛОВИЯХ СОVID-19}

Received: March 10, 2021

\begin{abstract}
The UHT milk market in the Russian Federation is actively developing and belongs to a promising direction of food industry. The UHT milk is a milk product that has undergone a process of heat treatment in which the milk is heated to a temperature of $1370 \mathrm{C}$, and kept at that temperature for 4 seconds before being cooled to room temperature. UHT milk retains almost all the ben-eficial properties of the original product, while it belongs to long-term storage goods and does not require the use of refrigeration equipment. The importance of the product has sharply in-creased during the quarantine imposed by the authorities during the COVID-19 pandemic. At the same time, there is a significant number of UHT milk brands on the consumer market, which leads to quite serious competition and necessitates studying the level of their competitiveness, especially for solving applied issues in the local geographic segment of the market. According to the author, today there is definitely a lack of comprehensive scientific methodological approaches to assessing the competitiveness and quality of UHT milk sold on the local market. Therefore, the purpose of the research was to assess the competitiveness and quality of UHT milk of various brands, presented on the market of Troitsk, Chelyabinsk region. The study assumes a complex methodology, which includes the following stages: 1) identification of the competitiveness of UHT milk by the index method of the ratio of prices and quality of the milk samples under study; 2) conducting a comprehensive assessment of the competitiveness of UHT milk brands presented in the local market, based on the primary marketing research of consumer preferences in
\end{abstract}

Abstract
Accepted: April 12, 2021

\author{
Written by: \\ Oleg Ilyasovich Katlishin \\ https://orcid.org/0000-0003-2869-2312 \\ SPIN: $9498-8542$
}

${ }^{6} \mathrm{PhD}$ in Economics, Associate Professor of Department of Commodity Research and Ex-amination of Goods, Perm State AgroTechnological University named after Academician D.N. Pryanishnikov, Russia; Associate Professor of Department of Economic Analysis and Statistics, Perm Institute, branch of REU named after G. V. Plekhanov, Russia. 


\section{AMAZONDA}

this segment of the dairy market; 3) identification of the level of competitiveness of milk trade marks on the basis of the economic method, which assumes their ranking by trade volume. On the basis of the obtained data, it is concluded that the most competitive are the samples of trade marks «Dairy River» and «Dairy Farmer».

Key Words: competitiveness, quality of UHT milk, price-quality method, turnover.

уровня конкурентоспособности торговых марок молока на основе экономического метода, предполагающего их ранжирование по объему торговли. На основе полученных данных делается вывод о том, что наиболее конкурентоспособными являются образцы торговых марок «Молочная речка» и «Молочный фермер».

Ключевые слова: конкурентоспособность, качество ультрапастеризованного молока, метод соотношения цены и качества, товарооборот.

\section{Introduction}

According to I. V. Buyanova, milk occupies a special place in consumer food basket, and its production is becoming a large industry in the Russian Federation (Buyanova, 2018). Indeed, milk and dairy products have a special place in the human diet. And in this case, ultra-relaxed milk is one of the most profitable acquisitions. Ultra-relaxed milk is a milk product that has undergone a process of heat treatment, in which the milk is heated to a temperature of $137^{\circ} \mathrm{C}$, for 4 seconds, after which it is sharply cooled to room temperature. We denote ultra-relaxed milk as an abbreviation UHT milk. The scientific position of L.G. Eliseeva deserves, according to which UHT milk is positioned as a ready-to-use safe product that has undergone gentle heat treatment, which retains all the benefits of milk (Eliseeva, 2016). Ultra-pasteurization of milk allows keeping most of the vitamins and proteins in the same quantity.

The volume of sales of milk with a long shelf life is increasing annually on the Russian market. Experts predict an increase in sales in this category, since UHT milk meets the main trends of modern life: it can be stored for a long time without a refrigerator and purchased for future use, thereby freeing up time for most important and useful things at home. Today people prefer products with a long shelf life. The demand for this group of products has increased sharply due to the quarantine introduced in Russia in connection with the COVID-19 pandemic. Due to the current situation, the demand for UHT milk has increased by $30 \%$.

And if in the Russian Federation this segment of the dairy market is relatively young and promising, then abroad it has been successfully developing for a long time. UHT milk is most common in Europe, Asia and South America. Scientists from Manchester have calculated that 7 out of 10 inhabitants of the European continent

prefer milk with a long shelf life. The share of UHT milk in Spain and Portugal has been at 97\% since 2017 and will grow to $99 \%$ by 2021, in Italy - since 2016 it has added $2 \%$ to $62 \%$ and will increase to $70 \%$ in the future.

In Europe, it is fashionable to buy eco-friendly products, and this has not bypassed UHT milk. Therefore, the British government in 2018 proposed to increase the share of UHT milk on the shelf from $90 \%$ by 2021 . In order to reduce the impact on the environment of refrigeration equipment, British scientists propose to increase the demand for UHT milk, because it does not require storage at low temperatures.

The situation in the world has changed significantly. This was influenced by the coronavirus infection. The pandemic has not spared any part of the industry. This also affected the dairy industry. At the moment, many forecasts are being revised and ways of solving the problems that have appeared are being sought.

The situation has changed significantly over the last three months of this year. If at the end of last year the forecast for the development of the dairy industry was stable, at the moment we do not know what to expect throughout 2020. After all, everyone understands that the situation with COVID-19 will not end in the near future, and there is also a high probability that a second wave of the pandemic will come. T.I. Rybalova notes that it is important to track the dynamics of dairy industry production caused by the spread of coronavirus infection COVID-19 (Rybalova, 2019).

The demand for products with a long shelf life has increased. This is evidenced by analytical data for European countries for March-April 2020. Digital data show that the demand for dairy 
products, primarily for butter, cheese, UHT milk, has grown by $25-30 \%$. A. Belov, however, notes how long this trend will last is a big question (Belov, 2020).

All of the above, as well as the breadth of the assortment and the growth in the supply of UHT milk from different brands, determines the relevance of the chosen topic and the object of research. Manufacturers pay special attention to this market segment, which leads to the fact that each manufacturer tries to produce quality products at an acceptable cost, that is, it creates high competition. The growth of competition in the consumer market requires analysis and assessment of the competitiveness of UHT milk brands for all target audiences: consumers, retail chains and manufacturers.

\section{Literature review}

Z. P. Matyukhina and E. P. Korolkova define ultra-high-temperature-processed milk as natural drinking milk subjected to heat treatment in order to comply with the established requirements of technical regulations for microbiological safety indicators and an increase in shelf life (Matyukhina \& Korolkova, 1998).

UHT milk is a demanded and popular product in the global and domestic markets, and this trend continues to gain momentum. According to IMACR GROUP estimates, the cumulative annual growth rate of the global UHT milk market from 2018 to 2020 amounted to $12.8 \%$ and by 2021 will reach USD 137.7 billion in monetary terms. The largest players in the UHT milk market are recognized leaders in the dairy market - Parmalat, Candia, Dairy Partners Americas, Nestle and Fonterra.

At present the volume of the UHT milk market in Russia is 1.9 billion liters, while the overall dynamics of the Russian milk market is assessed as positive. Every year the sector grows by $1.1 \%$, milk with a long shelf life adds $0.5 \%$. In 2017 , the market in monetary terms amounted to 253 billion rubles, where one third fell on UHT milk (Group of companies "Damate", 2020).

However, D. Simo, L. Mura, J. Buleca state that simultaneously with the tendency to saturate the market with various brands of UHT milk, competition between them is also intensifying (Simo, Mura, \& Buleca, 2016). J. W. Miller points out that the increase in goods that influence their competition is fully explained by the laws of the world market (Miller, 1998).
M. M. Galeev, A. S. Baleevskikh, O. I. Katlishin, E. R. Urazaev emphasize that increased competition in the food market took place in the consumer market in the Russian Federation as a result of accession to the WTO (Galeev, Baleevskikh, Katlishin \& Urazaev, 2014). Z. V. Almetova, V. D. Shepelev, N. A. Kuznetsov express the opinion that as a result of the movement of our country to create a common market and a single economic space within the Eurasian Economic Union, there has been an increase in competition for consumer goods of domestic producers (Almetova, Shepelev \& Kuznetsov, 2019).

In connection with the above, the degree of relevance of studying the methodological and methodological aspects of the competitiveness of milk in domestic and foreign economic science is growing. The author of this study relies on the point of view of A. I. Panyshev, according to which the competitiveness of a specific brand of ultra-pasteurized milk is understood as the totality of its characteristics, as well as the accompanying sale and consumption of services that distinguish it from similar products in terms of the degree of satisfaction of the consumer's needs, by the level of costs for its acquisition (Panyshev, 2018). In other words, competitiveness is equated with the ability of packaged milk to meet consumer expectations and its ability to be sold. A. Balkyte and M. Tvaronavičiene share the opinion that competitiveness is a market philosophy that defies any forecasts and calculations (Balkyte \& Tvaronavičiene, 2010).

According to A. D Magomedov, in order to calculate the competitiveness, it is necessary to know: 1) the interest of consumers; 2) the state of the market; 3) the behavior of competitors (Magomedov, 2013). Scientists R. L. Leibensperger and J. W. Griffith express the opinion that the strength of an enterprise's position in the market is determined by the competitiveness of its products and the ability to compete (Leibensperger \& Griffith, 2001). V. M. Poznyakovsky expresses the view that ehe competitiveness of goods is one of the most important factors for the development of the economy of enterprises, regions and even states, while the competitiveness of goods in the domestic and international markets is different (Poznyakovsky, 2017). D. K. Shevchenko and P. T. Chmil consider a product that combines high quality and a list of consumer requirements, including pricing ones, to be competitive (Shevchenko \& Chmil, 2017). 


\section{Materials and methods}

Within the framework of this article, the goal was to assess the competitiveness and quality of ultrapasteurized milk brands presented on the local market in Troitsk, Chelyabinsk region. The scientific hypothesis of the study put forward an opinion on the advisability of analyzing and assessing the competitiveness and quality of UHT milk. The achievement of this goal was carried out through the solution of the following tasks:

1. Revealing the competitiveness of ultrapasteurized milk by the index method of the ratio of price and quality of the studied milk samples.

2. Conducting an integrated assessment of the competitiveness of UHT milk brands presented on the local market based on primary marketing research on consumer preferences in this segment of the dairy market.

3. Revealing the level of competitiveness of milk trade marks on the basis of the economic method, which assumes their ranking by the volume of trade.

There are many methods for assessing the competitiveness and quality of dairy products: express methods (calculated by experts qualimetrically as the sum of points); graphic methods (graphs, diagrams are used, "competitiveness radars", which visualize the assessment of the competitiveness of a product); calculation of integrated and complex indicators. In carrying out the work, we used the following methods: monographic, analytical, organoleptic, sociological survey method, as well as marketing research methods, including the economic method, as well as the method for determining the price / quality ratio and the integrated indicator of competitiveness.

A whole range of different methods is used to analyze and assess competitiveness. The simplest method for assessing the competitiveness of a product is the index method, the essence of which is the ratio of product quality to its price. The higher the quality and the lower the price, the higher the competitiveness. The second method is integral. It is based on complex indicators of the choice of a particular product. With the help of the coefficient of weighting, according to the formula, points are calculated. The higher the score, the more competitive the product is. The third method is based on the volume of sales of a certain type of product or an economic method.
It is based on identifying consumer preferences using sales volume.

The first stage of the study was the selection of ultra-pasteurized milk samples of the trade marks «Fair Cow» (sample № 1), «Birskaya» (sample № 2), «Dairy Farmer» (sample № 3), «Dairy River» (sample № 4). To comply with the requirements for the typical and representativeness of the study, milk samples were selected for identical characteristics from a homogeneous group of dairy products: weight - 900 grams, fat mass fraction $3.2 \%$.

On the basis of preliminary research on the quality of selected milk samples, which are one of the stages of an end-to-end comprehensive scientific study and are not included in the content of this article (direct studies of the organoleptic and physicochemical indicators of the quality of milk samples were carried out not by the author of the article, but by colleagues in a special expert laboratories of Perm State AgroTechnological University named after Academician D. N. Pryanishnikov), their quantitative expert assessment of quality was carried out. In the course of the work, a sensory assessment of the organoleptic quality indicators of the studied milk samples was carried out. The group of experts was asked to evaluate in points the following indicators of the studied milk samples: appearance, texture, taste and smell, as well as color.

The appearance and color of milk should be an opaque white liquid. The consistency should be liquid, homogeneous, not sticky, without flakes. Taste and smell characteristic of milk, without foreign tastes and odors, with a slight aftertaste of boiling.

When assessing competitiveness by the pricequality method, a quantitative expert assessment of samples of the studied milk brands was carried out. Five experts jointly evaluated the abovedescribed indicators of the studied milk samples on a five-point scale: appearance, texture, taste and smell, color. The evaluation used the data of laboratory examinations and direct sensory expert assessment in the process of tasting. Further, at this stage, the competitiveness of milk was determined by the price-quality method. For this, the results of the point assessment are adjusted taking into account the weight coefficients. The weighting coefficients are also determined collectively by experts. 
When assessing competitiveness by the method of determining the ratio of price and quality, the formula $K=\sum_{i=1}^{z} m_{i} k_{i}$ (1) was used,

where $\mathrm{K}$ is a complex dimensionless indicator of the quality of the goods, in points;

$k_{i}-$ a dimensionless value that characterizes the value of each quality indicator, in points;

$m_{i}$-intragroup weighting coefficients of the i-th quality indicators within each group of properties;

$\mathrm{z}$ - the number of quality indicators.

In the course of the qualimetric assessment of quality, the experts determined the weighting coefficients of quality indicators, since they were rather heterogeneous and unequal. Thus, the weight factor was 2 for appearance, 3 for consistency, 4 for taste and smell, 1 for color.

Next, a direct calculation of the ratio of milk quality, expressed in points, and its price was carried out. The higher the quality-price ratio, more competitive the product is.

The second stage of the study was the determination of a complex (integrated) indicator of competitiveness based on the study of consumer preferences.

The analysis of the competitiveness of milk brands on the market of Chelyabinsk region through the calculation of the integrated indicator of competitiveness was completely based on the opinion of end consumers. The main criterion for the competitiveness of milk is the degree of satisfaction of end consumers' real needs. In the integrated calculation of the competitiveness of milk brands, the opinion of consumers about their sensory (quality) properties and other quality indicators, price, consumer packaging and labeling, and brand recognition was taken into account.

After analyzing consumer preferences, the results obtained are corrected by the coefficients of the significance of competitiveness criteria for consumers, and the results obtained are summed up by samples. The higher the final score, more competitive the brand is. In the direct comprehensive assessment of competitiveness, formula (1) was used, but it was adapted to the integrated assessment method.

At the last stage of assessing competitiveness, the most methodologically simple method was used - economic. This method compares the volume of trade for the studied brands for a comparable period. When solving the third problem, a simple ranking of the volume of proceeds by the studied trade marks was carried out: the higher the turnover, more competitive the UHT milk of this trade mark is.

\section{Results}

This publication provides a study of the competitiveness of UHT milk brand samples, typical for the local market in Troitsk, Chelyabinsk region: «Fair Cow» (sample № 1), «Birskaya» (sample № 2), «Dairy Farmer» (sample № 3), «Dairy River» (sample № 4).

As part of solving the first problem, a point-based expert assessment of the studied milk samples was carried out. The experts were asked to evaluate the following indicators of the studied milk samples on a five-point scale: appearance, texture, taste and smell, color. The result of the sensory assessment of milk is presented in Table 1. From the assessment of competitiveness by the price-quality method, a low-quality sample was excluded («Birskaya» trademark), since, according to the results of laboratory physical and chemical studies, it didn't correspond to GOST in acidity - it exceeded the norm by $9^{\circ} \mathrm{T}$ (degrees Turner). 
Table 1.

Sensory assessment results.

\begin{tabular}{|c|c|c|c|c|c|c|c|}
\hline \multirow[b]{2}{*}{$\begin{array}{l}\text { Indicator } \\
\text { name }\end{array}$} & \multicolumn{4}{|c|}{ Scale, level, score } & \multicolumn{3}{|c|}{$\begin{array}{l}\text { Result, point for UHT milk from different } \\
\text { manufacturers }\end{array}$} \\
\hline & 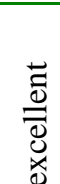 & $\begin{array}{l}8 \\
8 \\
80\end{array}$ & 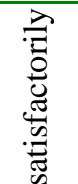 & 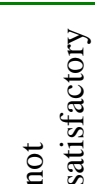 & «Fair Cow» & «Dairy Farmer» & $\begin{array}{l}\text { «Dairy } \\
\text { River» }\end{array}$ \\
\hline Color & 5 & 4 & 3 & $1-2$ & 25 & 20 & 22 \\
\hline Average score & & & & & 5 & 4 & 4,4 \\
\hline $\begin{array}{l}\text { Taste and } \\
\text { smell }\end{array}$ & 5 & 4 & 3 & $1-2$ & 20 & 15 & 25 \\
\hline Average score & & & & & 4 & 3 & 5 \\
\hline Appearance & 5 & 4 & 3 & $1-2$ & 25 & 25 & 25 \\
\hline Average score & & & & & 5 & 5 & 5 \\
\hline Texture & 5 & 4 & 3 & $1-2$ & 25 & 25 & 25 \\
\hline Average score & & & & & 5 & 5 & 5 \\
\hline Total & & & & & 95 & 85 & 97 \\
\hline
\end{tabular}

The experts recognized the ultra-pasteurized milk of «Dairy River» trademark as excellent quality products, since during the tasting the sum of points was the highest: color - 22 points, taste and smell -25 points, appearance -25 points, texture -25 points. The tasters gave the second place to «Fair Cow» trademark, since the following indicators were determined for it: color - 25 points, taste and smell - 20 points, appearance -25 points, texture -25 points. And the third place was given to «Dairy Farmer» trademark: color -20 points, taste and smell -15 points, appearance -25 points, texture -25 points.

However, the results of this point rating are not final, since they don't take into account the weight, the importance of various factors in the overall quantitative assessment of quality. Therefore, the final comprehensive assessment of the quality of drinking milk samples was carried out in Table 2, taking into account the weight coefficients of its various indicators developed by experts.

Table 2.

The results of the point assessment taking into account the weighting coefficient.

\begin{tabular}{lllll}
\hline Indicator name & Weighting factor & «Fair Cow» & «Dairy Farmer» & «Dairy River» \\
\hline Color & 1 & 5 & 4 & 4,4 \\
The obtained & & 5 & 4 & 4,4 \\
scores & 4 & 3 & 5 \\
$\begin{array}{l}\text { Taste and smell } \\
\text { The obtained }\end{array}$ & 4 & 12 & 20 \\
$\begin{array}{l}\text { scores } \\
\text { Appearance }\end{array}$ & 2 & 5 & 5 & 5 \\
The obtained & & 10 & 10 & 10 \\
scores & 3 & 5 & 5 & 5 \\
Texture & & 15 & 15 & 15 \\
The obtained & & 41 & 49,4 \\
scores & 46 & & \\
Total & & & 41 & \\
\hline
\end{tabular}

In this particular study, the use of weighting factors didn't change the alignment of forces in the ranking of the studied samples by quality. «Dairy River» trademark was also the best, followed by «Fair Cow». Based on a comparative expert-tasting assessment, the ratio of quality and price for each sample was determined. Table 3 shows the quality-price ratios for three samples of milk brands. 
Table 3.

Quality-price ratio for milk samples.

\begin{tabular}{llll}
\hline Samples & Quality indicator in points & Price for 1 kg, rub. & «Quality / price» ratio \\
\hline $\begin{array}{l}\text { Sample № 1 «Fair } \\
\text { Cow» }\end{array}$ & 46 & 53 & 0,87 \\
$\begin{array}{l}\text { Sample № 3 «Dairy } \\
\text { Farmer» }\end{array}$ & 41 & 51 & 0,8 \\
$\begin{array}{l}\text { Sample № 4 «Dairy } \\
\text { River» }\end{array}$ & 49,4 & 49 & 1,01 \\
\hline
\end{tabular}

The final data on the competitiveness of milk samples in this particular case correspond to the rating of milk in terms of its quality, and in fact, sensory organoleptic properties. On the basis of the data obtained, it can be concluded that among the samples under study, the sample № 3 has the most optimal price-quality ratio - «Dairy River» (JSC «MILKOM», Russian Federation, the Udmurt Republic of Izhevsk). The second place is taken by sample Sample № 1 «Fair Cow» (LLC «Chekmagushevsky dairy plant», Republic of Bashkortostan), and on the third place is sample № 3 «Dairy Farmer» (LLC «Ufagormolzavod», Russia, Republic of Bashkortostan).

To solve the second problem, namely to assess the competitiveness of UHT milk using the integrated indicator method, it was necessary to conduct a sociological survey. During the survey, the respondents were asked the question to determine the weighting factor: "What influences your choice when buying UHT milk?”

In the course of the sociological survey, it was revealed that the consumer, when choosing and buying UHT drinking milk, pays attention to its quality first of all (66 surveyed buyers have answered as follows). On the second place in terms of importance is the acceptable price (29 buyers out of 134 pay attention to it). Thus, the weight factor will be 0.49 for organoleptic qualities (sensory properties), 0.22 for the price, 0.13 for packaging design, 0.11 for labeling information, 0.08 for brand awareness. The selection and purchase criteria for UHT milk are shown in Figure 1.

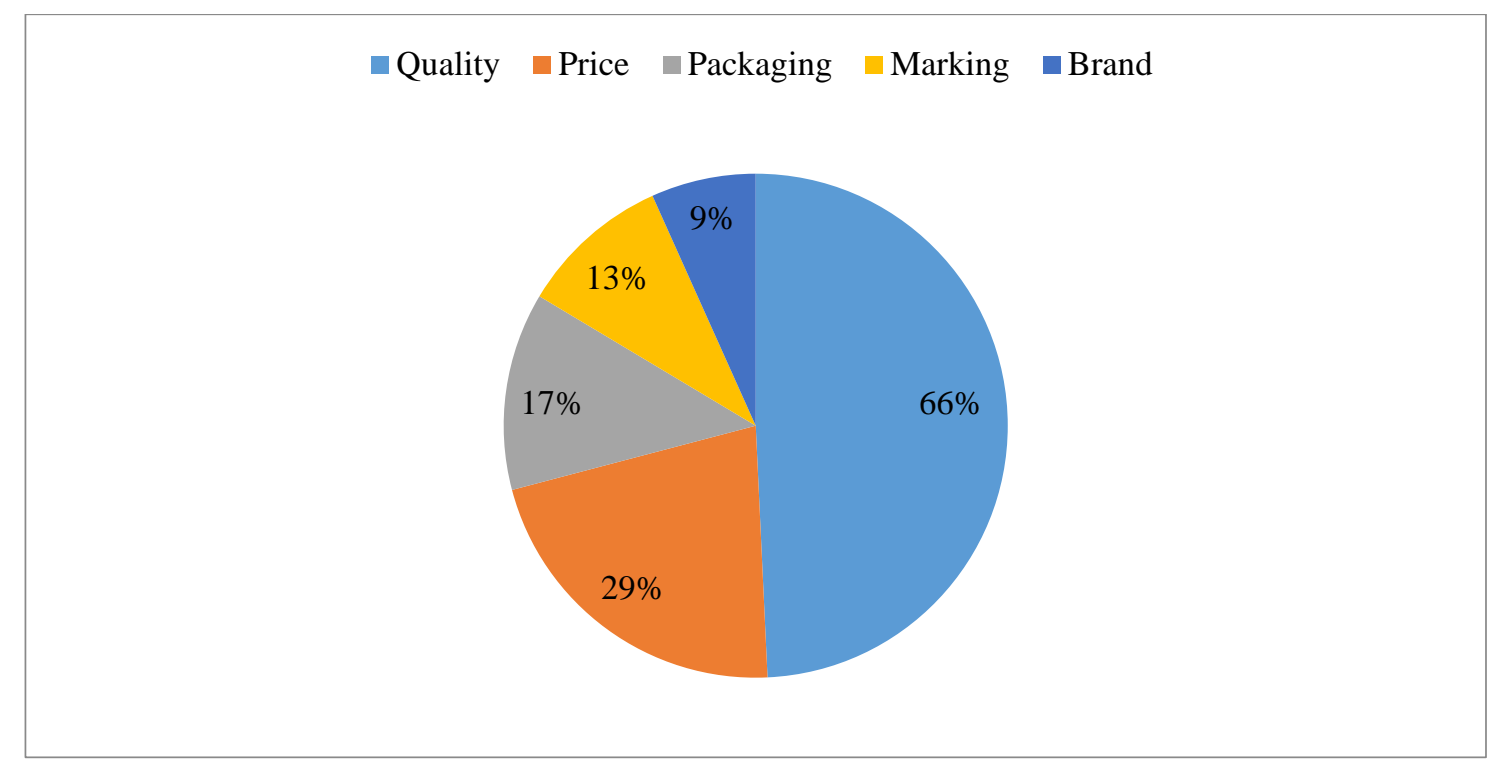

Figure 1. Criteria for selection and purchase of UHT drinking milk by consumers, in the number of responses.

Also, all respondents were asked to assess the studied milk brands on the Likert scale. The results of the assessment by the respondents of the studied UHT milk samples according to the Likert scale are presented in Table 4. 
Table 4.

The results of the respondents' assessment of the studied samples of ultra-pasteurized milk according to the Likert scale.

\begin{tabular}{|c|c|c|c|c|c|}
\hline \multirow[b]{2}{*}{ Indicator } & \multirow[b]{2}{*}{ Score } & \multicolumn{4}{|l|}{ Test samples } \\
\hline & & $\begin{array}{l}\text { «First taste» } \\
\text { (Sample № 1) }\end{array}$ & $\begin{array}{l}\text { «Podovinnovskoe } \\
\text { milk» (Sample № 2) }\end{array}$ & $\begin{array}{l}\text { «Chebarkul milk» } \\
\text { (Sample № 3) }\end{array}$ & $\begin{array}{l}\text { «New day» } \\
\text { (Sample № 4) }\end{array}$ \\
\hline \multirow{5}{*}{ Quality } & 5 & 65 & 54 & 63 & 59 \\
\hline & 4 & 32 & 39 & 29 & 36 \\
\hline & 3 & 2 & 5 & 8 & 4 \\
\hline & 2 & 1 & 2 & 0 & 0 \\
\hline & 1 & 0 & 0 & 0 & 0 \\
\hline \multirow[t]{3}{*}{ Average score } & & 4,61 & 4,45 & 4,55 & 4,51 \\
\hline & 5 & 38 & 51 & 49 & 65 \\
\hline & 4 & 41 & 28 & 33 & 31 \\
\hline \multirow[t]{3}{*}{ Price } & 3 & 14 & 20 & 18 & 4 \\
\hline & 2 & 5 & 1 & 0 & 0 \\
\hline & 1 & 2 & 0 & 0 & 0 \\
\hline \multirow[t]{2}{*}{ Average score } & & 4,08 & 4,29 & 4,31 & 4,61 \\
\hline & 5 & 72 & 75 & 71 & 71 \\
\hline \multirow{4}{*}{$\begin{array}{l}\text { Informative } \\
\text { marking }\end{array}$} & 4 & 26 & 23 & 27 & 28 \\
\hline & 3 & 2 & 2 & 1 & 1 \\
\hline & 2 & 0 & 0 & 0 & 0 \\
\hline & 1 & 0 & 0 & 1 & 0 \\
\hline \multirow[t]{2}{*}{ Average score } & & 4,70 & 4,73 & 4,67 & 4,70 \\
\hline & 5 & 91 & 42 & 56 & 39 \\
\hline \multirow{4}{*}{$\begin{array}{l}\text { Bright } \\
\text { packaging }\end{array}$} & 4 & 7 & 35 & 33 & 34 \\
\hline & 3 & 1 & 19 & 10 & 22 \\
\hline & 2 & 0 & 1 & 1 & 5 \\
\hline & 1 & 0 & 3 & 0 & 2 \\
\hline \multirow[t]{3}{*}{ Average score } & & 4,86 & 4,1 & 4,44 & 4,09 \\
\hline & 5 & 87 & 65 & 74 & 70 \\
\hline & 4 & 11 & 31 & 25 & 24 \\
\hline \multirow[t]{3}{*}{ Brand } & 3 & 1 & 2 & 0 & 4 \\
\hline & 2 & 1 & 1 & 1 & 0 \\
\hline & 1 & 0 & 1 & 0 & 2 \\
\hline Average score & & 4,8 & 4,58 & 4,72 & 4,6 \\
\hline
\end{tabular}

The obtained processed data from the respondents on the Likert scale were used to calculate the competitiveness of weighting factors indicator by multiplying them. Based on the results of the table (Table 4) and using the weighting coefficient, an integrated assessment of competitiveness was calculated (Table 5).

Table 5.

Calculation of the integrated indicator of the competitiveness of trade marks of UHT milk.

\begin{tabular}{llllll}
\hline Sign & $\begin{array}{l}\text { Weighting } \\
\text { factor }\end{array}$ & $\begin{array}{l}\text { «Fair } \\
\text { Cow» }\end{array}$ & «Birskaya» & $\begin{array}{l}\text { «Dairy } \\
\text { Farmer» }\end{array}$ & «Dairy River» \\
\hline $\begin{array}{l}\text { Organoleptic } \\
\text { properties }\end{array}$ & 0,49 & 4,57 & 3,39 & 4,65 & 4,87 \\
The obtained scores & & 2,24 & 1,66 & 2,28 & 2,39 \\
Price & 0,22 & 3,96 & 4,50 & 4,14 & 4,49 \\
The obtained scores & & 0,87 & 0,99 & 0,91 & 0,99 \\
Package design & 0,13 & 4,49 & 4,13 & 4,31 & 4,62 \\
\hline
\end{tabular}




\begin{tabular}{lccccc}
\hline The obtained scores & & 0,58 & 0,54 & 0,56 & 0,61 \\
Marking & 0,11 & 4,35 & 4,07 & 4,64 & 4,65 \\
The obtained scores & & 0,48 & 0,45 & 0,51 & 0,52 \\
Trademark & 0,08 & 4,22 & 4,12 & 4,44 & 4,64 \\
The obtained scores & & 0,34 & 0,33 & 0,35 & 0,37 \\
Total & 4,51 & 3,97 & 4,61 & 4,88 \\
\hline
\end{tabular}

On the basis of the integral method, we can conclude that the most competitive is the ultrapasteurized milk of «Dairy River» trademark, since it has the highest scores in all characteristics. UHT milk «Birskaya» is the least competitive, as it has the lowest score in almost all characteristics, except the price.
As part of solving the third problem, an economic method was applied, which implies ranking the brands of UHT milk by the volume of trade. The turnover of UHT milk in the shop of LLC «Agrotorg Pyaterochka» for January - June 2020 is presented in Table 6 .

Table 6.

UHT milk turnover in the shop of LLC «Agrotorg Pyaterochka» for January - June 2020.

\begin{tabular}{llllll}
\hline \multirow{2}{*}{$\begin{array}{l}\text { № } \\
\Pi / \Pi\end{array}$} & Indicator & $\begin{array}{c}\text { Test samples } \\
\text { Sample № 1 } \\
\text { «Fair Cow» }\end{array}$ & $\begin{array}{c}\text { Sample № 2 } \\
\text { «Birskaya» }\end{array}$ & $\begin{array}{c}\text { Sample № 3 } \\
\text { «Dairy Farmer» }\end{array}$ & $\begin{array}{c}\text { Sample № 4 } \\
\text { «Dairy River» }\end{array}$ \\
1. & $\begin{array}{l}\text { Implemented milk, } \\
\text { packages }\end{array}$ & 787 & 185 & 1522 & 1710 \\
& $\begin{array}{l}\text { Cost of one for 1 piece, } \\
\text { 2. }\end{array}$ & 53 & & & \\
rub & Trade turnover, rub & 41711 & 48 & 51 & 49 \\
4. & Competitiveness rank & 3 & 8880 & 77622 & 83790 \\
\hline
\end{tabular}

As a simple analysis of empirical data obtained directly from the fields, that is, from a retail outlet in Troitsk, which is part of the retail chain of «Agrotorg Pyaterochka» LLC (part of the X5 Retail Group), shows, the most demanded product from the analyzed is the ultrapasteurized milk of «Dairy River» trademark. On the second place is «Dairy Farmer» brand. «Fair Cow» trademark closes the top three in this homogeneous group of products. As a result of the analysis of turnover for the subgroup of UHT milk, the fact of an increase in demand for this product during the period of the announced quarantine in March-April 2020 was confirmed. During this period, UHT milk sales have been tripled.

\section{Discussion}

I. I. Dimitrakaki defines the competitiveness as a set of characteristics of a product and its accompanying sale and consumption of services that distinguish it from similar products in terms of the degree of satisfaction of the consumer's needs, in terms of the level of costs for its acquisition and operation (Dimitrakaki, 2015). E. V. Kolobanova and A. V. Semyanova believe that researchers single out three main features of the competitiveness of goods: satisfaction of specific needs of buyers; optimal ratio of quality and cost indicators; ensuring the best results of the enterprise in comparison with competitors (Kolobanova \& Semyanova, 2016). For example, K. A. Antoshkina believes that the higher the quality-price ratio, more competitive the product is (Antoshkina, 2019). The author agrees with this opinion, although only partially, using the method of assessing competitiveness by determining the price-quality ratio in his scientific research (Katlishin, 2018, 2020).

Professor E. P. Golubkov made a significant conclusion that the competitiveness of a product can change in one market depending on the segment, and since consumer preferences can change over time, the competitiveness of a product in one segment also changes over time (Golubkov, 1999). However, the time factor for all goods is different and doesn't always depend on the shelf life and use of the goods. For example, it is not necessary that preferences for dairy products will be of a shorter duration than for technically complex durable goods.

I. M. Lifits believes that the most accurate indicator of the competitiveness of a product is shown by the choice of direct consumers (Lifits, 2018). At the same time, it is necessary to take into account that the opinion of consumers doesn't arise by itself, but is formed as a result of 
being in a particular information environment and marketing efforts of manufacturers to promote their products in the form of advertising and PR. Therefore, competitiveness is also the ability of manufacturers to adapt to customer requirements, as evidenced by the words of Adam Smith: "We don't want our lunch from the benevolence of a brewer or butcher, but from their own interests" (Smith, 1993). Researchers A. N. Kara and A. P. Minina agree with this interpretation of the category "competitiveness" (Kara \& Minina, 2016).

According to A. A. Akhmetgareeva, competitiveness is the philosophy of the market, which is subject to forecasting (Akhmetgareeva, 2016). The author's interpretation of the understanding of competitiveness and methods of its assessment in relation to UHT milk integrates the opinions of many scientists who have studied this issue. For the purposes of his research, the author identifies the following methods of competitiveness of goods: index, integral, economic.

The author fully agrees with the opinion of K. A. Antoshkina, who considers the index method to be the simplest research method. From the point of view of K. A. Antoshkina, the index method consists in identifying the ratio of the quality of a product to its price: the higher the quality and the lower the price, more competitiveness the product is (Antoshkina, 2019).

The second method is integral. The integral method of assessing competitiveness is very subjective, since it is based on the opinion of buyers. A. I. Panyshev, applying the integral method, is based on complex indicators of the choice of a particular product. Using the weighting coefficient and calculating the total points, the researcher determines the level of competitiveness of food products: the higher the points, more competitive the product is (Panyshev, 2018).

The third method is based on the volume of sales of a certain type of product or an economic method. It is based on identifying consumer preferences by fixing the volume of sales.

Certainly each of the methods has its own pros and cons. However, it is the third method that appeals to the author of this article most of all. The economic method, being methodologically the simplest and at the same time the most accurate indicator of the market in practice, is not available to manufacturers, since it often represents information related to trade secrets. At the same time, being an accurate indicator, this method doesn't explain why the market situation has developed accordingly (Katlishin, 2018).

\section{Conclusions}

An expert quantitative assessment of the organoleptic indicators of the quality of UHT milk showed that the best quality is characterized by a sample of «Dairy River» trademark (sample № 4). The second place for the same indicator is taken by «Fair Cow» trademark (sample № 1). From a professional expert point of view, these are the best samples. And these trademarks the author recommends to buy for all categories of consumers.

Application of the method of integrated assessment of competitiveness revealed a slightly different arrangement of competitive positions in the market, different from the ideal picture recommended by experts.

The conducted marketing research using the direct sociological survey method helped to identify the most significant criteria for the competitiveness of UHT milk with a mass fraction of $3.2 \%$ fat in Troitsk market of Chelyabinsk region.

Despite the coronavirus crisis, the most important criterion for consumers was not price, but sensory subjective quality indicators, that is, taste characteristics. When making a purchase decision, price was only on the second place in terms of importance, and on the third place was package design. The brand factor in terms of importance for the aggregate sample of consumers was on the last place, which can be explained by the relative youth and still insufficient level of development of the UHT milk market. Hence, it is possible to recommend all manufacturers to strengthen their advertising activities and increase the efficiency of work to form consumer loyalty to their brand. The fact that sensory quality metrics are the most important for a consumer when making a purchase decision suggests that manufacturers should focus on these metrics in their quality management system.

Thus, as a result of calculating the integrated indicator of competitiveness, sample № 4 «Dairy River» trademark turned out to be the most competitive. The second place was taken by «Dairy Farmer» trademark (sample № 3), which 
bypassed sample № 1 «Fair Cow» due to higher consumer recognition. Putting on the «Dairy Farmer» trademark on the second place, consumers once again confirmed the role of the marketing and advertising system in shaping consumer preferences.

The results obtained from the analysis of competitiveness by the third method-economic, fully coincided with the rating of the competitiveness of UHT milk samples, identified on the basis of the previous integral method. The combined methodology for analyzing the competitiveness of UHT milk can be recommended to retail trade enterprises of this geographical segment when forming priorities in their assortment matrix.

\section{References}

Akhmetgareeva, A. A. (2016). Assessment of the competitiveness of product packaging. Modern society and power. No. 3(9), pp. 126-130.

Almetova, Z. V., Shepelev, V. D., \& Kuznetsov, N. A. (June, 2019). The integrative process of transport systems of the Eurasian Economic Union. In T. Arkhangelsk of the President of the Congress (Presidency), IOP Conference Series: Earth and Environmental Science. Symposium directed by Far Eastern Federal University, Vladivostok Branch of Russian Customs Academy, Vladivostok .

Antoshkina, K. A. (February, 2019). Competitiveness of milk from various manufacturers in the food market of the DPR. In V. Krishtafovich of the President of the Congress (Presidency). Quality and safety of goods: from production to consumption: collection of works conf. Symposium directed by Russian University of Cooperation, Moscow. Balkyte, A., \& Tvaronavičiene, M. (2010). Perception of competitiveness in the context of sus-tainable development: facets of "Sustainable competitiveness". Journal of Business Economics and Management, 11(2), pp. 341-365.

Belov, A. (2020). The coronavirus situation will affect the dairy industry throughout the year. Milknews. Recovered from https://milknews.ru/interviu-i-blogi/belovkoronavirus-moloko.html

Buyanova, I. V. (2018). Milk and dairy products technology. Production accounting and reporting in the dairy industry: a tutorial. Kemerovo: KemSU. Recovered

from https://www.studmed.ru/buyanova-ivtehnologiya-celnomolochnyhproduktov_d6863b1e30f.html
Dimitrakaki, I. (2015). Quality Competitiveness of the dairy enterprises. Economics and Management, No. 11, pp. 26-33.

Eliseeva, L. G. (2016). Commodity research and examination of food products: textbook. Moscow: MCFER. Recovered from https://mybook.ru/author/kollektivavtorov/tovarovedenie-odnorodnyh-gruppprodovolstvennyh-to/read/

Galeev, M. M., Baleevskih, A. S., Katlishin, O. I., \& Urazaev, A. R. (2014). The influence of the WTO on the results and prospects of the agroindustrial complex and food industry. Life Science Journal, No. 11, pp. 408-411.

Golubkov, E. P. (1999). Fundamentals of marketing: textbook. M.: Finpress. Recovered from https://docplayer.ru/27864762-E-pgolubkov-osnovy-marketinga-uchebnik.html

Group of companies "Damate". (2020). Milk was pushed to quality. How the dairy market developed in 2019. Recovered from https://acdamate.com/press-

center/press/moloko-podtolknuli-k-kachestvukak-razvivalsya-molochnyy-rynok-v-2019godu/

Kara, A. N., \& Minina, A. P. (2016). Analysis of approaches to the essence of the concept of "competitiveness". Karelian scientific journal. Vol. 5. No. 1(14), pp. 45-47.

Katlishin, O. I. (2018). Assessment of the competitiveness of pasta sold in Perm market. Competitiveness in the global world: economics, science, technology, No. 6, pp. 40-42.

Katlishin, O. I. (2020). Evaluation of competitiveness, classification and calculation of customs payments of chicken breeds realized on the market. Amazonia Investiga, 9(27), pp. 391400.

https://amazoniainvestiga.info/index.php/amazo nia/article/view/1256

Kolobanova, E. V., \& Semyanova, A. V. (2016). Ways to improve the competitiveness of goods. New Science: Experience, Traditions, Innovations, No. 12-1 (119), pp. 169-170. Recovered from https://www.elibrary.ru/download/elibrary_274 77053_98004281.pdf

Leibensperger, R. L., \& Griffith, J. W. (2001). The extended enterprise: advancing suppliercustomer competitiveness. International Journal of Manufacturing Technology \& Management, 3(1-2), pp. 142.

Magomedov, A. D. (2013). Improvement of the system of commodity circulation of milk and dairy products in the Russian Federation (doctoral thesis), All-Russian Research Institute of Agricultural Economics of the Russian Agricultural Academy, Moscow. Recovered from 
https://www.dissercat.com/content/sovershenstv ovanie-sistemy-tovarodvizheniya-moloka-imolochnoi-produktsii-v-rossiiskoi-feder/read Matyukhina, Z. P., \& Korolkova, E. P. (1998). Commodity science of food products: a textbook for the beginning. Moscow: Academy. Recovered from https://bookree.org/reader?file $=1503532 \& p g=4$ Miller, J. W. (1998). Assessing farm-level competitiveness of milk production in Mexico and the United States, (unpublished Ph.D. thesis). Texas A\&M University, Texas.

Panyshev, A. I. (2018). Analysis of the competitiveness of sausage products on the market of Perm region. Competitiveness in the global world: economics, science, technology, No. 2, pp. 75-78.

Poznyakovsky,

V. M.

(Ed.).

(2017). Examination of milk and dairy products. Quality and safety. Novosibirsk: Siberian
University Publishing House. Recovered from https://biblioclub.ru/index.php?page=book\&id= 57551

Rybalova, T. I. (2020). Results of 2019. Dairy industry, No. 3, pp. 39-42. Recovered from https://moloprom.ru/2020/03/itogi-2019-goda/ Shevchenko, D. K., \& Chmil, P. T. (2017). Competitiveness and product quality. Economy, No. 4. P. 8-9. Recovered from https://www.elibrary.ru/download/elibrary_288 73715_43814217.pdf

Simo, D., Mura, L., \& Buleca, J. (2016). Assessment of milk production competitiveness of the Slovak Republic within the EU-27 countries.Agricultural Economics, 62(10), pp 482-492.

Smith, A. (1993). Research on the nature and causes of the wealth of nations. Petrozavodsk: Petrokom. 